\title{
The role of Female Movement Champion (PKK) as the social glue in urban community planning: Case study applied research of "Kota Layak Anak" Program
}

\author{
Irene Sondang Fitrinitia ${ }^{1 *}$, Esti Suyanti ${ }^{2}$, and Lita Sari Barus ${ }^{2}$ \\ ${ }^{1}$ Institute of Urban Innovation, Yokohama National University, Japan \\ ${ }^{2}$ School of Strategic and Global Studies, Universitas Indonesia, Indonesia
}

\begin{abstract}
Sustainable Development Goals Number 11 initiates the existence of sustainable cities and communities. Creating this sustainable, livable, and harmonization between city and community should consider the multi-direction of development in response to dynamic change. It can be a top-down or bottom-up process. Participatory methods become a backbone for urban communities to build a livable environment in the micro-scale of planning. It can be shown from the existence of female champions such as members of the PKK group lead many community programs in household neighborhoods. This study wants to describe the female cadre's participatory action through the program Kota Layak Anak and analyzing to what extent the role of female cadre as a glue for the community to maintain the collectiveness among them. This article is applied research when data collecting base on information and observation through community activity. It also adds by content analysis as a comparison. We like to capture and analyze regard to the female champion and its relatedness with the urban community. The existence of female champion is significant to city planning to preserve social cohesion. Not only as a driving force for the collective program but also become a social glue among the community.
\end{abstract}

\section{Introduction}

Like two sides of the coin, urban development can be managed as the good and bad effects of one system. Sometimes the process has a subtle difference, so we do less recognize whether it is sustainable or not. The result is a big gap between what is the planning and implementation at the city level. Social connections become important to generate sustainability, which occurs from the intersection between physical and institution development [1]. Social connections are usually part of civil society and occur in each community in the city. It has become the importance of a social element in innovationgenerating advancement [2]. Also, it creates a livable community that is definitely as one that is safe, attractive, socially cohesive, and inclusive, and environmentally sustainable, with reasonable settlement [3]. helix consider the civil society to combine top-down and bottom-up approaches. Usually the business as usual approach is a top down approach

\footnotetext{
* Corresponding author: irenesondang20@gmail.com
} 
resulting in disparity in several areas and might not achieve inclusive growth. Since the picture of the city just according to one side which is the decision maker, it will become an issue when the idea rarely synchronizes with the concept that is needed from civil society that dwells in the area. Though the planning practice is dominated by top-down approaches, the pursuit of a planning system that considers the local needs more deeply and allows greater citizen participation encompasses an acceptable objective. It is known as a system that tackles some of the weaknesses of the top-down approaches. [4]; [5]. A synergizing will occur while community participation plays an active part in the innovation system collaborating with other stakeholder like government, private sector and academicians. As part of making cities more sustainable like what had been delivered in Sustainable Development Goals number 11, it needed a breakthrough way not just business as usual. By improving urban planning and management in a participatory and inclusive way can trigger the occurrence of a sustainable city.

One of the breakthroughs is from the model of community participation as part of people's development on an urban scale. Thriving communities would typically provide an excellent social infrastructure [6] to shape a sustainable community. Community organizations and local champions like females become a driving force also as social infrastructures. The movement like PKK in most cities in Indonesia is becoming spearhead in community activities. They become as bridging media and "social glue" among the community itself and with activities outside. However, there is also a limitation because of the existence of female movement in the neighborhood most drives by government programs. Hence the continuity depends on the availability of the projects or external funding.

PKK is a social institution whose roles are intended to improve family welfare through various skills development activities related to hygienic life and family education. All the activities involving female members at the RW (a neighborhood unit level in Indonesia city similar like hamlet). PKK has ten main programs implemented in RT (the smallest unit in neighborhood and RW environments, most of which have been determined from the central level (ministry, city/district government)—increasing members' capacity, especially women, in mobilizing various activities of the surrounding environment and neighborhood.

This paper aims to describe how important the female champion's role in urban development is based on the activity evaluation in Kota Layak Anak program; it can show to readers that female champions can be "living tools" to enhance the sustainable community in supporting the city development. The Kota Layak Anak program was chosen as a case study because it shows how the top-down program works on a micro-scale blended with the local community planning.

Hence, the structure of this paper consists of six parts. Introduction that will explain the background of the research context. Next are the literature and methodology as the basic and guideline of thinking in this paper. Results will be defined into three parts: the implementation of Kota Layak Anak in Depok, the role of female cadre to enhance the Kota Layak Anak program, and the potential impact of female cadre existence deliver sustainable development. The last part is the conclusion as keynotes in this paper, which can be replicated in other cases.

\section{Method}

As we know, urban development is not even a single way approach, only from the government or private sector or only from the community. It needs to synergize many approaches to generate a sustainable system that balances what society needs and the government plan. The longstanding concept that correlates regional development and society was explored in detail by Ferdinand Tonnies as German sociologist famous with 
Gemeinschaft and Gesellschaft in 1855-1936 that influenced the subsequent typological approaches of Weber, Durkheim, Simmel. They indirectly later influenced Louis Wirth, Robert Redfield, Becker, and Talcott Parsons [7]. According to previous studies, Gesellschafts are closely related to the urban community typically. Wirth's classical article about "Urbanism as a Way of Life" told about three population characteristics that cause the distinctive urban lifestyle in Gesellschafts context: number, the density of settlement, and the degree of heterogeneity. The author also said the increased population density of the city requires a greater tolerance of individual differences but results in more competition, exploitation, and disorder. The more urban heterogeneity means the more complex stratification system [7]. Even it is an old theory, but it remains in current situations. In mega-urban development, we are not talking regarding the massive infrastructure and public facilities and the solidness of urban communities. It is challenging since we know the mega-urban society is quite heterogeneous. However, support of citizen engagement and mutual exchange to improve communities' lives is one thing to complete by the state [2].

The bottom-up planning process is one of the principles to engage the community to grow urban development. As part of applied urban development, bottom-up planning is inextricable with social and political conditions [8]. Recently this bottom-up approach has become a crucial issue to develop inclusive cities. Since the planning practice has dominated top-down planning theories since 1960, then in around 1990 tending to equate urban planning to politics and planning theory and shifted to a more bottom-up approach [5]. Therefore, many models pursue a planning mechanism to allow a local participant to complete the absence from what the top-down has implemented. Planning standard is one example in the bottom approach, which finds a mechanism more inclusionary, open-style structure of discussions among the various stakeholders of any given local community [9]. Bottom-up planning might be used for effective activities and regulation suitable for society; it also designs a positive vibe, social interaction among communities that can trigger a sustainable society. People center development as principal to enforce the bottomup approach. However, some limitations are found when the bottom up approach guides regional or strategic urban planning, which cannot facilitate the allocation and the location of supralocal facilities. To this context, a top-down approach is still the obtainable choices for practical planning development [5].

Community development as part of the bottom-up planning is a program that focuses on reinforcing and improving quality of life among communities, addressing problems that have been identified by the community. It builds upon existing skills and strengths within the community [10]. At first, most community development activities were initiated by the non-government sectors and supported by multinational development agencies. Still, recently the government adopted this way to enhance inclusivity. Therefore, many governments promoted development projects aimed at environmental security, social renewal, and income generation [11]. At least there are three goals, such as 1. giving change to the neighborhood's economic cycle, improving the physical environment, and strengthening social bonds between people among the community.[12][10] Community development with similar contexts such as community engagement, capacity building, and participation are all empowerment [13].

Moreover, community development should have principles to measure whether it is successful or not. Such principles might identify issues that affect community lives, through developing solutions, to implementation. Five majors had identified as a result of the community development program in the community, such as (1) community leadership, (2) knowledge-building, (3) community networking, (4) valuing community, and (5) supporting information [14]. Below is the description of the principles: 
Table 1. The Principles of community development [14]

\begin{tabular}{|l|l|}
\hline \multicolumn{1}{|c|}{ Principles } & \multicolumn{1}{c|}{ Definition } \\
\hline Community leadership & $\begin{array}{l}\text { The community's capacity to establish and develop a shared vision and } \\
\text { common objective for local progress }\end{array}$ \\
\hline Knowledge-building & $\begin{array}{l}\text { The capacity to enhance skills, knowledge, and awareness to stimulate } \\
\text { the learning process }\end{array}$ \\
\hline Community networking & $\begin{array}{l}\text { community partnership with local institutions and other development } \\
\text { agencies to foster local development processes }\end{array}$ \\
\hline Valuing community & $\begin{array}{l}\text { understanding local communities and involving them in developmental } \\
\text { activities }\end{array}$ \\
\hline Supporting Information & $\begin{array}{l}\text { supporting, reliable and timely information assists the community in } \\
\text { taking advantage of available opportunities }\end{array}$ \\
\hline
\end{tabular}

The embedded concept that relates to community development is participatory development. Participatory means are inviting to have roles in the solution of any issuesdriven in the community. Usually, the participatory action is triggered by the local champion in the community. In the urban context and developing country, many of them are females and housewives who care for their environment. Women's involvement in neighborhood planning and development is typical in urban areas, especially in developing countries. Emancipative women have a crucial role in development recently, increasing share of leadership roles [15] — a gender-sensitive of urban planning thieves when emancipative roles occur from the woman as a driving force.

To complete this article is based on a resume of what we have done for community development projects in 2019. First is applied research, which became one way we had to collect the data and information. Secondly, we use content analysis from the preview research to compare what we got from the program in Depok and the desk study result. The methods flow is described in Figure 1. We were focused on enhancing the Kota Layak Anak Program in one area in Depok, Indonesia. We had a case study in Kelurahan Tirtajaya by developing a committee and routine activity through a participatory method involving the community and neighborhood stakeholders. We are supported by the community development funding from Universitas Indonesia. After eight months, we completed the activity that boosted the local organization in the sub-district. Exploring the report, we add some points of view from the applied research and evaluation findings. We found that members of the PKK or female driving force in neighborhood-scale were joined and initiated to establish each program of Kota Layak Anak. Therefore, in this paper, we overlay the Kota Layak Anak Implementation with the female movement champion (PKK). We assume that this female movement might be social glue in the context of urban community planning. 


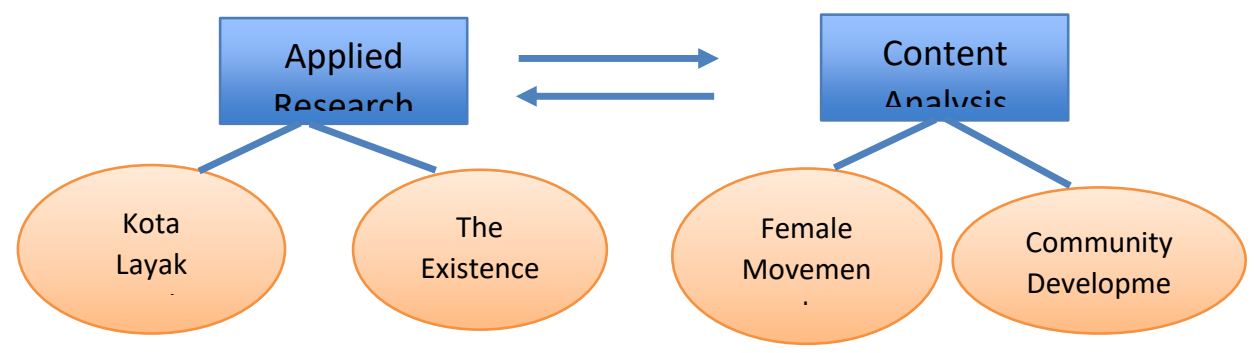

Fig. 1. Research Flow for this Article

\section{Results and discussion}

\subsection{The implementation of Kota Layak Anak}

Kota Layak Anak is a national program that started in 2006 for five cities as a pilot project in Indonesia adopted from the UNESCO concept. In Indonesia, some criteria should be fulfilled if a city can be labeled as Kota Layak Anak. Generally, the city must provide public facilities that consider children, education, child protection, and children's right to have comfort, life, and happiness. It is described into 31 indicators as benchmarks that pass down to each city/municipality and into sub-districts. Kota Layak Anak Program is based on the Ministerial regulation of women's empowerment and child protection Number 11 of 2011 where a city/district development system that integrates the commitments and resources of government, society, and business that are planned comprehensively and sustainably in policies for programs and activities to fulfill children's rights.

Depok is categorized as Kota Layak Anak that has a child-friendly program at the RW level. Depok's achievement as a child-friendly city is supported by many stakeholders, including programs up to the RT and RW levels. For this reason, several RWs in each subdistrict in Depok City has been designated as child-friendly RWs. Optimization of the Task Force Working Group is carried out in synergy with other community organizations, namely Posyandu, youth organizations, RT and RW administrators, and other community leaders. RW that has been designated now is still in progress to fulfill the 31 indicators of child-friendly area. At the RW level, the implementation of this program should carry out children's rights, grouped into six institutions, and 5 (five) clusters of child rights.

The implementation of child-friendly RW by identifying children in their perception due to living space was carried out in RW 08, Tirtajaya Village, Sukmajaya District, Depok City. The children were divided into four groups and asked to describe the playroom's concept and the atmosphere of the desired living environment. As part of the participatory process, the discussion group acknowledges the children's voice according to their perspective. Children's perceptions regarding the environment in which they live are presented in the following Figure 2. 


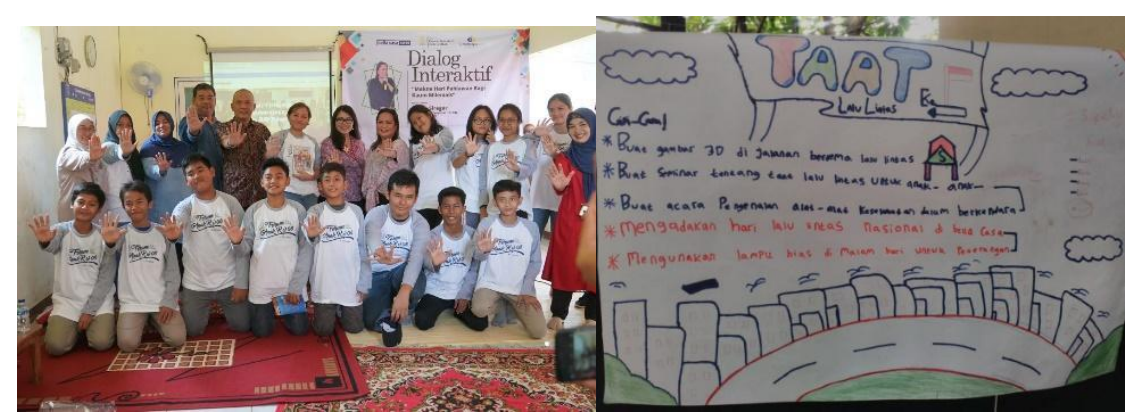

Fig. 2. Children Perception and Declaration of Children Forum

The process is not only until the planning phase by having their perception but also maintaining children's activity in the neighborhood. Strengthening children's understanding of rights and obligations is carried out with assistance by child experts, Posyandu members, PKK, and Task Force Working Group. This activity was disseminated as the preliminary stage of forming a children's forum at the RW level. Involving children in forums is a form of participation to know the perceptions and preferences of children. Below as mention in table 2 is the criteria categorized as a child-friendly RW based on it:

Table 2. Criteria of Child-friendly RW

\begin{tabular}{|c|c|c|}
\hline No & Component & Description \\
\hline 1 & Child Friendly Families & $\begin{array}{l}\text { - Children have health insurance card, Education Guarantee } \\
\text { Card, and / or complete the } 12 \text { year compulsory education; } \\
\text { - Children have a birth certificate; } \\
\text { - Healthy house; Maintain safe, clean and healthy children's } \\
\text { snacks; Smoke free house; } \\
\text { - Put the best interests of the child; } \\
\text { - Keep away domestic violence }\end{array}$ \\
\hline 2 & $\begin{array}{l}\text { Child-Friendly RW } \\
\text { Physical Environment }\end{array}$ & $\begin{array}{l}\text { - Clean, green and healthy; Clean sewer } \\
\text { - Having a children's playground } \\
\text { Having a reading corner / teaching and learning garden for } \\
\text { children; } \\
\text { - Having posters / announcements about the dangers of smoking, } \\
\text { drugs, and free sex }\end{array}$ \\
\hline 3 & $\begin{array}{l}\text { Child-Friendly RW } \\
\text { Social Environment }\end{array}$ & $\begin{array}{l}\text { - Implementing a Clean and Healthy Lifestyle (PHBS); } \\
\text { - Friendly, caring and protecting children; } \\
\text { - Respect children's rights; } \\
\text { - Maintain order and security } \\
\text { - Having child protection management }\end{array}$ \\
\hline 4 & $\begin{array}{l}\text { Institutionalization at } \\
\text { the Child-Friendly RW }\end{array}$ & $\begin{array}{l}\text { - Having a written collective agreement to protect children's } \\
\text { rights; } \\
\text { - Having a Child Forum / Children's Group organization; } \\
\text { - Child-friendly RW Level with work plan and disaggregated } \\
\text { data; } \\
\text { - Activity groups that are functioning well, such as Posyandu, } \\
\text { integrated Holistic BKB-PAUD, etc }\end{array}$ \\
\hline
\end{tabular}




\begin{tabular}{|c|c|c|}
\hline 5 & $\begin{array}{l}\text { Involving Child } \\
\text { Participation }\end{array}$ & $\begin{array}{l}\text { - In drafting regulations and development activities through } \\
\text { deliberations on RW and Musrembang. } \\
\text { - Listening to children's aspirations about children's hopes and } \\
\text { concerns } \\
\text { - Developing children's talents, arts and creativity } \\
\text { - Hearing children's voices / views related to national holidays, } \\
\text { etc. } \\
\text { - Making children a "reporter" and "pioneer" }\end{array}$ \\
\hline
\end{tabular}

\subsection{The role of Female Champion (PKK) in Kota Layak Anak (Child-Friendly City/ RW) program}

According to our findings in the applied research last year through the Kota Layak Anak Program, we found that the significant role to drive and motivate the neighborhood community is a female champion in PKK at RW level as we see in one RW in Kelurahan Tirtajaya, PKK as a driving force for various activities in the smallest community. Implementation of the PKK at the RW levels to materialize and implement programs that have been developed previously at the district or city level.

PKK activists (members) in citizens' association levels are generally women who are housewives. In the broad context of PKK, members are all community members who are at the forefront of increasing family empowerment. Still, persons who are designated with this task are housewives in the neighborhood. They have duties to implement the 10 PKK Main Programs, as shown in Figure 3. Members carry out the development of child-friendly citizens association as part of the PKK program through religious activity, education, and society approaches.

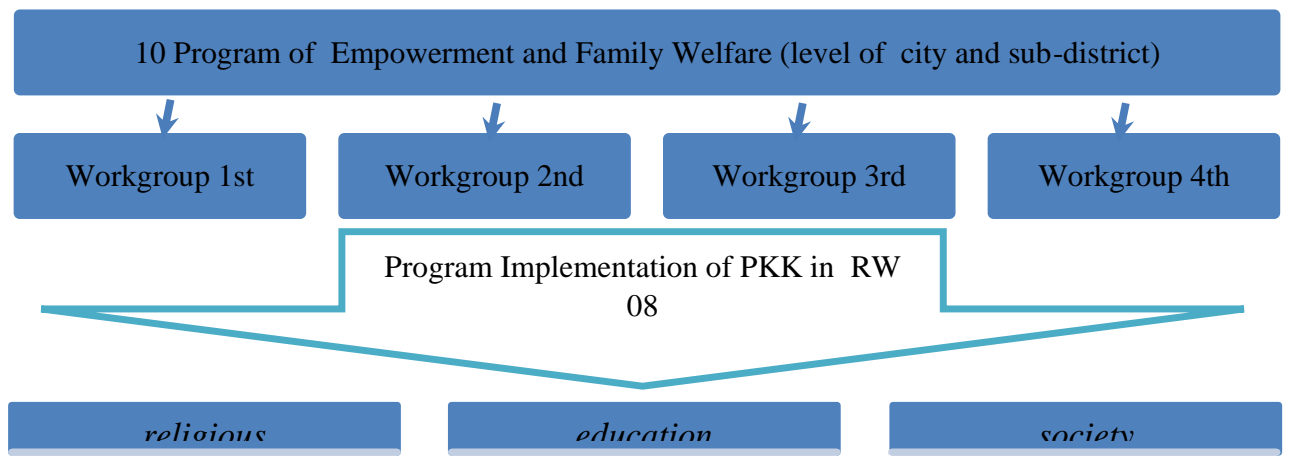

Fig. 3. Approach to Implementing the Empowerment and Family Welfare Program in RW 08

These three things can bind family members into community groups in RT and RW environments. PKK female champions socialize various successful child-friendly RW programs and integrate children's activities in existing communities. Observations made through applied research in 2019 showed the role of a female champion as follows:

1. Mostly member who takes roles for child-friendly in Kelurahan Tirtajaya (kelurahan is similar with sub district) a female member associated with PKK and Task Force Working Group.

2. Task Force Working Group child-friendly RW inseparable with the task of the female member in PKK through event Bina Keluarga Balita (BKB)- an event 
related with baby nurturing and Bina Keluarga Remaja(BKR)- an event related with youth development, also other informal female activity in the neighborhood

3. Posyandu (Neighborhood healthcare) is a center of family interaction that plays a role in strengthening communication between residents with dominated by females. So far, Posyandu has been at the forefront of BKB and BKR activities.

4. The indicators towards a child-friendly RW were indirectly developed through activities initiated by female members in PKK's various activities and projects.

At first, the establishment of a child-friendly RW is a top-down approach mandated by the national government. However, the implementation needs to synergize with various existing activities that have been running in the neighborhood. PKK members carry out their functions related to the development of child-friendly RWs that still face challenges such as (1) the hegemony of their citizens who come from various cultural, economic and social diversity; (2) high activity mobility; (3) individually urban residents; (4) female members still do not understand how to integrate child-friendly city indicators into implementing Child-Friendly RW development. This challenge becomes an obstacle in the social bonding process between families and the child-friendly RW development program. The role and participation of families supporting the development of child-friendly RWs have not received full support from all communities.

\subsection{Anchoring Female Champion in PKK for bottom-up planning and participation in the local or neighborhood scale}

As we know from the literature review, bottom-up planning needs contribution from as many stakeholders in any stage program. Champions of the bottom-up programs at the smallest level in the RT and RW are female members who are mostly housewives. This dual role of becoming a female champion is more comfortable to become agents of "social glue" that can connect communication between families and between residents in various government program activities. Government programs such as family development activities for toddlers and youth families, children's forums are easily communicated in informal activities (through religious activity, arisan, and social media groups). This approach will build people's trust to be actively involved in developing a more inclusive neighborhood. Since the female champion in PKK is a key-changer, increasing capacity building is a highly encouraging activity. Measuring the effectiveness of the existence of female champions through PKK will be evaluated through the principles that have been developed from Garlick 1999 [14]. Though it will develop in the Australian context, it has a similarity in the urban context. Below is table 3 is the observation measurement of the PKK activities in overall:

Table 3. The Role of Female Champion According to Community Development Principles

\begin{tabular}{|l|l|l|}
\hline Principles & \multicolumn{1}{|c|}{ Definition } & The Role of Female Champion in Implementation \\
of PKK
\end{tabular}




\begin{tabular}{|l|l|l|}
\hline $\begin{array}{l}\text { Knowledge- } \\
\text { building }\end{array}$ & $\begin{array}{l}\text { The capacity to enhance skills, } \\
\text { knowledge, and awareness to } \\
\text { stimulate the learning process }\end{array}$ & $\begin{array}{l}\text { Female champions receive training related to } \\
\text { integrated services at least 2 times a year at sub- } \\
\text { district levels. Other training in developing child- } \\
\text { friendly RWs also carried out in an integrated } \\
\text { Kelurahan level. The training increases the } \\
\text { capacity of members in providing services to the } \\
\text { community and developing strategic programs of } \\
\text { child-friendly RWs }\end{array}$ \\
\hline $\begin{array}{l}\text { Community } \\
\text { networking }\end{array}$ & $\begin{array}{l}\text { community partnership with } \\
\text { local institutions and other } \\
\text { development agencies to foster } \\
\text { local development processes }\end{array}$ & $\begin{array}{l}\text { Several RWs have formed partnerships such as } \\
\text { with Puskemas, related agencies to provide } \\
\text { counseling for their residents. Applied research } \\
\text { joined with SKSG UI has also strengthened the } \\
\text { capacity of female cadres to become pioneers as } \\
\text { behavior changes in their environment. Another } \\
\text { program partnership was the following CSR } \\
\text { program from the private sectors. }\end{array}$ \\
\hline $\begin{array}{l}\text { Valuing } \\
\text { community }\end{array}$ & $\begin{array}{l}\text { understanding } \\
\text { communities and involving } \\
\text { them in developmental activities }\end{array}$ & $\begin{array}{l}\text { In the case of child-friendly RW, the } \\
\text { understanding of community is reflected in the } \\
\text { role of children. They were allowed to be } \\
\text { involved in sharing the idea of a comfortable } \\
\text { environment as playgrounds. }\end{array}$ \\
\hline $\begin{array}{l}\text { Supporting } \\
\text { Information }\end{array}$ & $\begin{array}{l}\text { supporting, reliable and timely } \\
\text { information assists the } \\
\text { community in taking advantage } \\
\text { of available opportunities }\end{array}$ & $\begin{array}{l}\text { Female champions are involved in all existing } \\
\text { social media. Social media is the main channel for } \\
\text { communicating various programs and activities. } \\
\text { for example, for child-friendly, there was RW } \\
\text { homepage has been developed as a socialization } \\
\text { medium for child-friendly RW activities }\end{array}$ \\
\hline
\end{tabular}

\section{Conclusion}

Community participatory-led development in neighborhood communities is important in completing any kind of program from external (government, academic and private sectors). As we see from the case of Kota Layak Anak or child-friendly RW in Kelurahan Tirtajaya has been successful because of female champions in PKK. They take roles in most of the events. However, some challenges should consider with first it came from the internal female champion in PKK, such as less understanding about some community concepts. Secondly, it comes up from the external female champion or community such as heterogeneity, individually urban dwellers, and high activity residents. Moreover, female champions become a means and an end of the program in the context of participatory and engagement development. As a means, female champions could be "living tools" to trigger, stimulate, and boost the community in developing their neighborhood. In city planning, they can be agents to preserve social cohesion. Meanwhile, as an end, the female champion as an asset in the community becomes "social glue" among the community.

\section{Acknowledgments}

Most material we got from Hibah Pengabdian Masyarakat titled Optimalisasi Peran Kader PKK dalam Implementasi RW Ramah Anak di Kota Depok in 2019 funded by UI. 


\section{References}

1. E. Klinenberg, Palaces for the people: How social infrastructure can help fight inequality, polarization, and the decline of civic life, (London, Penguin, 2018)

2. K. Borkowska, M. Osborne, Locating the fourth helix: Rethinking the role of civil society in developing smart learning cities, Intl. Rev. Educ. 64, 355-372 (2018)

3. M. Lowe, C. Whitzman, H. Badland, M. Davern, L. Aye, D. Hes, I. Butterworth, B. Giles-Corti, Planning healthy, liveable and sustainable cities: How can indicators inform policy? Urb. Pol. and Res. 33, 131-144 (2015)

4. P. Sabatier, Top-Down and Bottom-Up Approaches to Implementation Research: a Critical Analysis and Suggested Synthesis, J. of Pub. Pol. 6, 1, 21-48 (1986)

5. I. Pissourios, Top-Down and Bottom-Up Urban and Regional Planning: Towards a Framework for The Use of Planning Standards, Euro. Spa. Res. and Pol. 21, 1 (2014)

6. H. Parr, Mental Health and Social Space: Towards Inclusionary Geographies? (Wiley, 2008)

7. Lyon, L, The Community in Urban Society, (Waveland Press, Inc, United States of America, 1999)

8. A.-Ph Lagopoulos, Urban Planning, Poleology and Land Uses, (Athens, Technical Chamber of Greece, 2009)

9. P. Healey, Collaborative Planning: Shaping Places in Fragmented Societies, (Macmillan, 1997)

10. K.G. Amakye, Understanding community development in Sekyere Central District, Ghana, Ban. J. of the Glo. Sou. 4 (2017)

11. S. Cohen, Mobilizing communities for participation and empowerment. In Participation for social change, ed. J. Servos, T.L. Jacobson, and S.A. White, (New Delhi, Sage, 1996)

12. T. Peter, A. Barr, S. Hashagen. Achieving better community development. London: Community Development Foundation, (2000)

13. F. Campbell, L. Hughes, T. Gilling, Reaching out: community engagement and health (London, Improvement and Development Agency, 2008)

14. S. Garlick, The Australian history of government intervention in regional development, Sustainable Rural Development, (FinalReport, Greening Australia, 1999)

15. S. Brieger, C. Francoeur, C. Welzel, W. Ben-Amar, Empowering Women: The Role of Emancipative Forces in Board Gender Diversity J. of Bus. Eth. 155 (2017) 